\title{
Multiple Equilibria between Fertility Rates and Pension Levels Based on the Target Level of Government Debt
}

\author{
Hideki Nakamura', Masaya Yasuoka² \\ ${ }^{1}$ Faculty of Economics, Osaka City University, Osaka, Japan \\ ${ }^{2}$ Faculty of Economics and Business Administration, the University of Kitakyushu, Kitakyushu, Japan \\ E-mail: hnakamur@econ.osaka-cu.ac.jp, yasuoka@kitakyu-u.ac.jp \\ Received August 1, 2011; revised August 26, 2011; accepted September 2, 2011
}

\begin{abstract}
We show that when the government has a target debt level, multiple equilibria exist in the relationship between fertility rates and pension levels. One is associated with a high fertility rate and a high pension level. The other is associated with a low fertility rate and a low pension level. If the government fails to provide adequate security for individuals during their retirement years, it would result in a failure of coordination between the government and individuals.
\end{abstract}

Keywords: Fertility, Pensions, Target Level of Government Debt, Multiple Equilibria

\section{Introduction}

The fertility rate in Japan has been decreasing, while the ratio of elderly people to the total population has been increasing. In addition, the Japanese government has attempted to reduce the number of issued government bonds by implementing the Reform of Fiscal Structure Law in 1997, because the government debt in Japan had increased significantly during the 1990s. This led to considerable controversy over the sustainability of the pay-asyou-go (PAYG) social security scheme in an aging society with fewer children and a large public debt ${ }^{1}$.

Should the government reduce the pension level in order not to increase the government debt as the pensionable proportion of the population rises? This paper assesses the possible relationship between the level of pension and the fertility rate when the government has a target for restricting the level of government debt. Pension levels affect lifetime income, which in turn affect the fertility rate. We show that given income taxes or consumption taxes, there exist multiple equilibria between pension levels and fertility rates. If the government chooses to set pensions at a low level, the fertility rate of

\footnotetext{
${ }^{1}$ Member countries of the European Union must maintain a ratio of government debt to GDP less than $60 \%$ in line with the Maastricht Treaty. In addition, a decline in the fertility rate and growing public debt are also evident in South Korea and Germany.

${ }^{2}$ In Japan and some European developed countries, including Italy, Germany, France, and Sweden, the correlation between the fertility rate and the ratio of pension benefit to labor income is high.
}

those dependent on such pensions decreases during their child-rearing years. A low pension level means that individuals cannot count on a reasonable income during their retirement years. Thus, they would seek to have fewer children during their younger years so as to reduce their household living expenses. The government then cannot increase the pension level because of the low level of tax revenue. On the other hand, if the government chooses to fix pensions at a higher level, this would tend to increase the fertility rate, as the prospect of larger pensions enables individuals to consider having more children. The government, in due course, obtains more tax revenue, because a higher fertility rate eventually expands the size of the taxpaying labor force relative to the pensionable group. Thus, the government should provide adequate security for individuals during their retirement years not to cause a failure of coordination between the government and individuals ${ }^{2}$.

We must emphasize the following points. Assuming a balanced government budget, Zhang [1], Groezen, Leers, and Meijdam [2], Groezen and Meijdam [3], and Hirazawa and Yakita [4] examined the effects of the PAYG social security scheme on fertility and welfare. As in their models, our model also considers endogenous fertility, in that children are assumed to be consumption goods. By introducing a target level of government debt, Futagami, Iwaisako, and Ohdoi [5] showed that multiple equilibria exist in the relationship between productive government spending and economic growth. Considering 
a situation in which population aging causes a heavy burden of social security payments, Ono [6] showed that the effects of pension reform and population aging on capital accumulation are different between potential two equilibria. This paper shows that multiple equilibria exist in the relationship between the pension level and the fertility rate because the existence of a target level for government debt yields a complementary relationship between the government and individuals through the pension system.

\section{Model}

We consider a small, open, overlapping-generations model. Individuals live in three periods. In the first period, the cost of child rearing is paid for by parents. In the second period, during which individuals are working, they decide how much to consume, how much to save, and how many children to have. They have to pay income taxes during this time ${ }^{3}$. In the third period, they receive the interest payments and a pension and consume their incomes. The government collects income taxes and issues bonds used for providing pensions while maintaining a target level of government debt. Firms are assumed to be perfectly competitive. The interest rate which is exogenously given is assumed to be constant. The wage rate also remains constant.

\subsection{Individuals}

The utility maximization problem for an individual born in period $t-1$ is expressed as:

$$
\begin{aligned}
& \max _{n_{t}, c_{1 t}, c_{2 t+1}} \alpha \ln n_{t}+\beta \ln c_{1 t}+(1-\alpha-\beta) \ln c_{2 t+1}, \\
& \text { s.t. } \quad c_{1 t}+\frac{c_{2 t+1}}{r}+z n_{t}=(1-\tau) w+\frac{p}{r},
\end{aligned}
$$

where $0<\alpha, 0<\beta$, and $\alpha+\beta<1 . n_{t}$ is the number of children born in period $t, c_{1 t}$ and $c_{2 t+1}$ are the consumption levels in periods $t$ and $t+1$, respectively, $\tau$ is the income tax rate, $p$ is the pension level, $z$ is the cost of child rearing, $r$ is the gross interest rate, and $w$ is the wage rate.

The first-order conditions of the utility maximization problem yield:

$$
c_{1 t}=c_{1}=\beta\left[(1-\tau) w+\frac{p}{r}\right],
$$

\footnotetext{
${ }^{3}$ It is widely argued in Japan that consumption taxes should be increased because of growing public debt. Assuming consumption taxes obtains the same results.

${ }^{4}$ If we assumed technological progress exogenously, we would consider the dynamics of ratio of public debt to national income. However, our results would remain intact.
}

$$
\begin{gathered}
c_{2 t+1}=c_{2}=(1-\alpha-\beta) r\left[(1-\tau) w+\frac{p}{r}\right], \\
n_{t}=n=\frac{\alpha}{z}\left[(1-\tau) w+\frac{p}{r}\right] .
\end{gathered}
$$

The relationships between consumption in periods $t$ and $t+1$ and the fertility rate in period $t$ are linear because of the log-linear function of utility. The number of children is proportionate to their parents' lifetime income.

\subsection{The Government}

The government finances the pension system by two methods: levying income taxes and issuing bonds. Its budget constraint can be written as:

$$
B_{t+1}=r B_{t}+N_{t-1} p-N_{t} \tau w,
$$

where $B_{t}$ is the government debt in period $t$, and $N_{t}$ is the population born in period $t-1$.

GDP per capita is constant in our model. Thus, we consider the debt-per-capita dynamics ${ }^{4}$. These dynamics are represented as:

$$
b_{t+1}=\frac{r}{n} b_{t}+\frac{p}{n^{2}}-\frac{\tau w}{n},
$$

where $b_{t} \equiv B_{t} / N_{t}$, which is public debt per capita, and $N_{t+1} / N_{t}=N_{t} / N_{t-1}=n$.

The government is assumed to have a target level of debt per capita, which is represented by $\bar{b}>0$. By controlling the income tax rate and the pension level, the government tries to satisfy $\bar{b}$ which is represented as:

$$
\bar{b}=\frac{r}{n} \bar{b}+\frac{p}{n^{2}}-\frac{\tau w}{n} .
$$

When the government follows (6), a negative primary balance implies that $\mathrm{r} / \mathrm{n}<1$ must hold for convergence.

\section{Multiple Equilibria}

Figure 1 shows the relationship between the fertility rate and the pension level represented by (5) and (7). Given $\bar{b}$ and $\tau$, (5) implies a linear relationship. A rise in the pension level causes an increase in the fertility rate, because it increases the level of lifetime income. Since higher pensions provide individuals with added security after their retirement, it allows them to have more children. On the other hand, (7) represents a nonlinear relationship between the fertility rate and the pension level. When the fertility rate is low, the government can pay only low pensions. It is difficult to maintain the target level of government debt because of the low level of tax revenue. A higher pension level becomes possible with a 


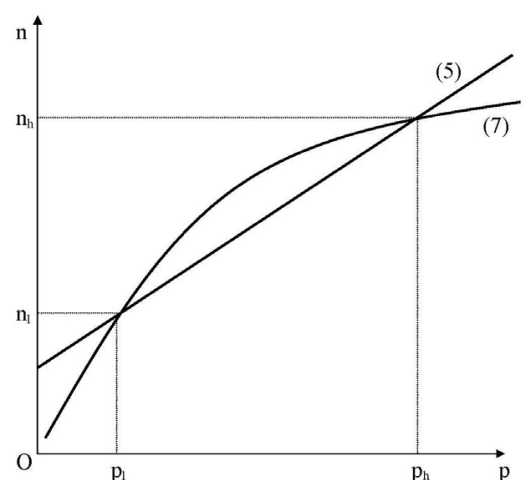

Figure1. Relationship between fertility rate and pension level.

higher fertility rate because of the higher level of tax revenue. It is easier for the government to maintain its target level of debt.

Using (5) and (7), the fertility rate in equilibrium can be represented as:

$$
\begin{aligned}
& n_{l}=2\left[A+\left(A^{2}-4 B\right)^{1 / 2}\right]^{-1}, \\
& n_{h}=2\left[A-\left(A^{2}-4 B\right)^{1 / 2}\right]^{-1},
\end{aligned}
$$

where $A \equiv \frac{1}{1-\tau}\left(\frac{z}{\alpha w}+\frac{\bar{b}}{w}-\frac{\tau}{r}\right)$ and $B=\frac{\bar{b}}{r(1-\tau) w}$. We assume that $A>0$ and $A^{2}-4 B>0$.

There exist multiple equilibria between the fertility rate and the pension level. Equation. (7) implies $p_{l}$ and $p_{h}$ which correspond with $n_{l}$ and $n_{h}$, respectively. When the pension level represented by $p_{l}$ is low, the fertility rate represented by $n_{l}$ is low. On the other hand, when the pension level represented by $p_{h}$ is high, the fertility rate represented by $n_{h}$ is high. If the government can make young individuals believe they will receive the large pension, they will have more children. The government can then provide higher pensions. However, if the government fails to make them believe this, they will choose to have a lower number of children. This will eventually force the government to provide the low pension level to maintain the budget. Thus, if the government provides a lower pension level, it would cause a failure of coordination between the government and individuals. In addition, although the level of labor income is identical in both equilibria, the income level during the retirement with the high fertility rate is higher than that with the low fertility rate. This is because a higher pension level is possible.

Let us examine the comparative statistics:

$$
\partial n_{l} / \partial \bar{b}>0, \quad \partial n_{h} / \partial \bar{b}<0, \quad \partial n_{l} / \partial \tau>0 \text { and } \partial n_{h} / \partial \tau<0
$$

First, an increase in the target debt level implies that the line representing (7) shown in Figure 1 shifts downward, because the burden of debt on the government budget decreases. Consequently, an increase in the target debt level then tends to raise the low fertility rate and lower the high fertility rate. If the government sets a low target level to avoid incurring a large debt in an aging society with fewer children, it will reduce the already low fertility rate. Note that given the tax rate, a high target level would make it difficult for the government to maintain its budget, and the equilibria may disappear. Next, an increase in the income tax rate implies that when the line representing (5) in Figure 1 shifts downward, the line representing (7) also shifts downward. Here, although an increase in the tax rate may induce individuals to have fewer children, it also allows the government to fund higher pensions. In our model, the latter effect dominates the former. Consequently, although an increase in the tax rate decreases the high fertility rate, it increases the low fertility rate.

\section{Conclusions}

When the government has a target level of debt, there exist multiple equilibria between the fertility rate and the pension level because of a strategic complementary relationship between the government and individuals. If the government cut the level of pensions so as not to increase the government debt, it would take away relief for individuals' old age, and, thereby, it would cause a failure of coordination between the government and individuals.

\section{References}

[1] J. Zhang, "Social Security and Endogenous Growth," Journal of Public Economics, Vol. 58, No. 2, 1995, pp. 185-213. doi:10.1016/0047-2727(94)01473-2

[2] B. V. Groezen, T. Leers, L. Meijdam, "Social Security and Endogenous Fertility: Pension and Child Allowances as Siamese Twins,” Journal of Public Economics, Vol. 87, No. 2, 2003, pp. 233-251. doi:10.1016/S0047-2727(01)00134-7

[3] B. V. Groezen, L. Meijdam, "Growing Old and Staying Young: Population Policy in an Aging Closed Economy," Journal of Population Economics, Vol. 21, No. 3, 2008, pp. 573-588. doi:10.1007/s00148-006-0067-x

[4] M. Hirazawa, A. Yakita, "Fertility, Child Care Outside the Home, and Pay-as-You-Go Social Security,” Journal of Population Economics, Vol. 22, No. 3, 2009, pp. 565583. doi:10.1007/s00148-007-0153-8

[5] K. Futagami, T. Iwaisako, R. Ohdoi, "Debt Policy Rule, Productive Government Spending, and Multiple Growth Paths,” Macroeconomic Dynamics, Vol. 12, No. 4, 2008, pp. 445-462. doi:10.1017/S1365100508070235 
[6] T. Ono, "Social Security Policy with Public Debt in an Aging Economy,” Journal of Population Economics, Vol.
16, No. 2, 2003, pp. 363-387. 